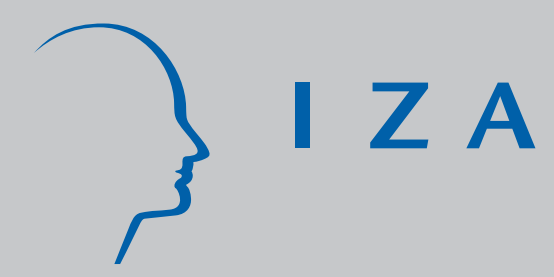

IZA DP No. 973

Structural Estimates of the Intergenerational Education Correlation

Christian Belzil

J örgen Hansen

December 2003 


\title{
Structural Estimates of the Intergenerational Education Correlation
}

\author{
Christian Belzil \\ Centre National de Recherche Scientifique, University of Lyon 2, \\ CIRANO, CIREQ and IZA Bonn \\ Jörgen Hansen \\ Concordia University, CIRANO, \\ CIREQ and IZA Bonn
}

\author{
Discussion Paper No. 973 \\ December 2003
}

\author{
IZA \\ P.O. Box 7240 \\ D-53072 Bonn \\ Germany \\ Tel.: +49-228-3894-0 \\ Fax: +49-228-3894-210 \\ Email: iza@iza.org
}

This Discussion Paper is issued within the framework of IZA's research area Mobility and Flexibility of Labor. Any opinions expressed here are those of the author(s) and not those of the institute. Research disseminated by IZA may include views on policy, but the institute itself takes no institutional policy positions.

The Institute for the Study of Labor (IZA) in Bonn is a local and virtual international research center and a place of communication between science, politics and business. IZA is an independent, nonprofit limited liability company (Gesellschaft mit beschränkter Haftung) supported by Deutsche Post World Net. The center is associated with the University of Bonn and offers a stimulating research environment through its research networks, research support, and visitors and doctoral programs. IZA engages in (i) original and internationally competitive research in all fields of labor economics, (ii) development of policy concepts, and (iii) dissemination of research results and concepts to the interested public. The current research program deals with (1) mobility and flexibility of labor, (2) internationalization of labor markets, (3) welfare state and labor market, (4) labor markets in transition countries, (5) the future of labor, (6) evaluation of labor market policies and projects and (7) general labor economics.

IZA Discussion Papers often represent preliminary work and are circulated to encourage discussion. Citation of such a paper should account for its provisional character. A revised version may be available on the IZA website (www.iza.org) or directly from the author. 
IZA Discussion Paper No. 973

December 2003

\section{ABSTRACT \\ Structural Estimates of the Intergenerational Education Correlation*}

Using a structural dynamic programming model, we investigate the relative importance of family background variables and individual specific abilities in explaining cross-sectional differences in schooling attainments and wages. Given scholastic ability, household background variables (especially parents' education) account for $68 \%$ of the explained crosssectional variations in schooling attainments. When the effects of household background variables on ability are also taken into account, the percentage raises to $85 \%$. However, individual differences in wages are mostly explained by abilities. Only $27 \%$ of the explained variation in wages is accounted for by parents' background variables as opposed to $73 \%$ by unobserved abilities (orthogonal to family background variables). When scholastic ability is correlated with family background variables, ability endowments explain as much as $81 \%$ of individual wages.

JEL Classification: J2, J3

Keywords: intergenerational education correlation, endogenous schooling, household characteristics, dynamic programming

Corresponding author:

Christian Belzil

IZA

P.O.Box 7240

53072 Bonn

Germany

Tel.: +492283894 161

E-mail: belzil@iza.org

\footnotetext{
* An earlier version of this paper was presented at the Conference "The Econometrics of Strategic Decision Making" which was held at Yale University (Cowles Foundation) in May 2000. We would like to thank Jean-Marc Robin and John Rust for useful comments. Belzil thanks the Social Sciences and Humanities Research Council of Canada for generous funding. The usual disclaimer applies.
} 


\section{Introduction}

Individual schooling attainments are one of the key components of the level of human capital in an economy. They are an important determinant of income distribution and are often thought to be one of the key factors explaining the wealth of nations as well as cross-nation di ßerences in economic growth. ${ }^{1}$ At the micr o level, it is customary to assume a strong correlation between one's schooling attainment and household background variables (especially parents' education). The e®ects of household back ground variables on individual schooling attainments can take various forms. While enrolled in school, young individuals typically receive parental support. Although parental support is usually unobservable to the econometrician, it is expected to be highly correlated with household background variables. At the same time, innate ability, also correlated with household background variables, should have an impact on the decision to attend school and on labor market wages.

The net e eects of household background variables on individual schooling attainments are far from obvious. On the one hand, households who have higher income may transfer more resources to their children and reduce the opportunity cost of school attendance. On the other hand, wealthier households also face a higher opportunity cost of spending time with children and may reduce their time investment in children. The erect of innate ability on school attendance is also undear. If skill endowments are strongly correlated with household background variables (especially father's and mother's education), those young individuals raised in households endowed with a high level of human capital will have a high level of school ability but will also have a high level of market ability (absolute advantage in the labor market).

The simultaneous eßects of parents background variables on the opportunity cost of schooling and on both school and market abilities are at the center of the strong cross-sectional correlation between household background variables and individual schooling attainments. Whether individual schooling attainments are more a eected by household background variables or innate ability remains an open question.

The main objective of the present paper is to estimate a structural model of schooling decisions which will allow us to answer the following 2 questions.

1. How much of individual di ßerences in schooling attainments is explained by individual ability heterogeneity as opposed to di ßerences in household background variables?

\footnotetext{
${ }^{1}$ Indeed, the recent revival of neo-classical growth models is largely based on human capital theory (Lucas, 1988). A lthough the links between schooling and private wages is well established at the micro level, the relationship between economic growth and education is substantially weaker. This paradox is currently the object of a large amount of work (see Topel, 1999, for a survey).
} 
2. How much of predicted wages is explained by individual ability heterogeneity as opposed to di ßerences in household background variables?

As far as we know, and despite the amount of work devoted to the determinants of schooling, none of these questions have been precisely answered to date. In this paper, we estimate two complementary versions of a ${ }^{-}$nite horizon dynamic programming model on a panel of white males taken from the $\mathrm{N}$ ational Longitudinal Survey of Youth (NLSY). T he panel covers the period from 1979 until 1990.

First, we estimate a model speci ${ }^{-}$cation (Model 1 ) where individuals are endowed with exogenous household characteristics and innate abilities. Labor market ability a rects both wages and employment rates. We assume that individual ability is the sum of a deterministic (observable) component capturing the e Rect of household background variables and an unobserved component representing idiosyncratic ability which is orthogonal to household background variables. Using the parameter estimates, we simulate the model and recover the implied correlations between schooling attainments and all the determinants of interest. In this framework, it is impossible to distinguish the eßects of parents' background on the per-period utility of attending school from the eßects household background variables on scholastic ability.

As a second step, we estimate a version of the model in which Armed Forces Quali ${ }^{-}$cation Tests (A FQT ) scores are used as an observable (although imperfect) measure of scholastic ability. As AFQT scores are known to be strongly correlated with household background variables, it is possible to distinguish between an ability component correlated with household characteristics and a residual component which is orthogonal to family background variables. This approach allows us to measure the direct eßects household background variables on the per-period utility of attending school (net of the e Rects of these same variables on scholastic ability).

Altogether, the results provide a relatively clear picture of the importance of family background variables Given scholastic ability, household background account for $68 \%$ of the explained cross-sectional variations in schooling attainments. Interestingly, more than one half of this $68 \%$ is explained by father's and mother's schooling al one. However, around one half of the residual source (approximately 15\%) of explained variations due to abilities is also explained by family background variables. When taken as a whole, family background variables may therefore account for $85 \%$ of the explained cross-sectional variations in schooling attainments. However, individual di ßerences in wages are mostly explained by ability endowments. Parents background variables account for $27 \%$ of the explained variations in wages while unobserved abilities (orthogonal to family background variables) account for $73 \%$. When scholastic ability is correlated with family background variables, the role of ability is even stronger. A bility endowments explain as much as $81 \%$ of wages while only $19 \%$ is explained by 
family background variables.

The main features of the paper are the following. A brief review of the literature is found in Section 2. Section 3 is devoted to the presentation of the dynamic programming model. The main empirical results are discussed in Section 4. The conclusion is in Section 5.

\section{The Correlation between Family Background Variables and Schooling Attainments}

In recent years, numerous papers concerned with the dynamics of schooling attainments have stressed the importance of parental background and family environment as one of the major determinants of the probability of transiting from one grade level to the next. This positive correlation between individual schooling attainments and parents education is well established in simple correlation analysis (K ane, 1994), in reduced-form dynamic models such as Cameron and Heckman (1998, 2001) as well as in structural dynamic programming models such as Keane and Wolpin (1997), Eckstein and Wolpin (1999) and Belzil and Hansen $(2001,2002)$. Most studies set in a dynamic framework also point out that the other major determinant is permanent unobserved heterogeneity, which may represent unobservable fact ors such as individual speci ${ }^{-} \mathrm{c}$ taste for schooling, academic ability, motivation, di ßerences in discount rates or any other unobservable trait which is time-invariant. ${ }^{2}$

As a starting point, the strong intergenerational education correlation may be best illustrated by simple OLS estimates of the eRects of parents' background variables on schooling. These are in Table 1 . The parents background variables are those normally used by researchers who use the NLSY and are discussed in more details in the next section. The regressions indicate that schooling increases with father's schooling, mother's schooling, family income and that schooling is higher for those who have been raised by both parents (we refer to this variable as the $\backslash$ nuclear family" ). On the other hand, schooling decreases with the number of siblings and is lower for those living in the south and in rural areas. None of these results are surprising. As pointed out by $\mathrm{C}$ ameron and Heckman, father's and mother's education are by far the most important family background variables (they account for as much as $83 \%$ of the explained variations).

As of now, the erects of household background on schooling attainments have only rarely been investigated within a full structural framework. Eckstein and Wolpin (1999) have estimated a - nite mixture model of school attendance and work behavior. While their model does not allow them to estimate the direct erect of household background variables and perform a variance decomposition,

\footnotetext{
${ }^{2} \mathrm{C}$ amer on and Heckman refer to parents' education and individual abilities as IIong run factors".
} 
they can merge actual data on schooling attainments with data on household characteristics and use Bayes' rule to relate those data to unobserved type probabilities. Belzil and Hansen (2001) use a dynamic programming model of schooling decisions in order to estimate the returns to schooling. In their model, the utility of attending school depends explicitly on household background variables but, after conditioning on schooling, labor market outcomes are una Bected by parental background variables. ${ }^{3}$ W hile empirical evidence reported in all the papers cited above indicate that school attendance increases with household background variables, the relative importance of household characteristics and unobserved abilities remains di \pm cult to evaluate.

\section{The Model}

Individuals are initially endowed with household background variables, innate ability and a rate of time preference (denoted $\rho$ ). Given their endowments, young individuals decide sequentially whether it is optimal or not to enter the labor market or continue accumulate human capital. Individuals maximize discounted expected lifetime utility. The control variable, $d_{t}$, summarizes the stopping rule. When $d_{t}=1$, an individual invests in an additional year of schooling at the beginning of period $t$. When $d_{t}=0$, an individual leaves school at the beginning of period $t$ (to enter the labor market). Every decision is made at the beginning of the period and the amount of schooling acquired by the beginning of date $t$ is denoted $S_{t}$. As it is di \pm cult to write down a full structural model which would include all the eßects that household background variables variables may have on the probability of transiting from one grade level to the next, we specify a reduced-form function for the utility of attending school. The function is allowed to dep end on various household background variables as well as individual unobserved ability.

The instantaneous utility of attending school is

$$
U^{\text {school }}(.)=X_{i}^{0} \delta+\psi\left(S_{i t}\right)+v_{i}^{\xi}+\varepsilon_{i t}^{\xi}
$$

where $X_{i}$ contains the following variables: father's education, mother's education, household income, number of siblings, household composition at age 14 and regional controls. The number of siblings is used to control for the fact that, other things equal, the amount of parental resources spent per child decreases with the number of siblings. The household composition variable (Nuclear Family) is equal to 1 for those who lived with both their biological parents (at age 14) and is likely to be correlated with the psychic costs of attending school. The

\footnotetext{
${ }^{3}$ Sauer (2001) investigates the impact of education - nancing means on lifetime earnings. $\mathrm{H}$ is analysis is analysis targeted toward a very particular sample of elite $\mathrm{L}$ aw School graduate students.
} 
geographical variables are introduced in order to control for the possibility that direct (as well as psychic) costs of schooling may di ßer between those raised in urban areas and those raised in rural areas, and between those raised in the south and those raised in the north. Yearly household income is reported as of 1978 and measured in units of $\$ 1,000$. The term $v_{i}^{\xi}$ represents individual heterogeneity (ability) a recting the utility of attending school. It is discussed in more details below. The utility of attending school is allowed to depend on the level of schooling in $a^{\circ}$ exible fashion. This is done using a spline function approximation of $\psi\left(S_{t}\right)$. Finally, $\varepsilon_{t}^{\xi}$ represents a stochastic utility shock and is assumed to be i.i.d normal with mean 0 and variance $\sigma_{\xi}^{2}$.

We assume that individuals interrupt schooling with exogenous probability $\zeta\left(S_{t}\right)$ and, as a consequence, the possibility to take a decision depends on a state variable $\mathrm{I}_{t}$. When $\mathrm{I}_{t}=1$, the decision problem is frozen for one period. If $\mathrm{I}_{t}=0$, the decision can be made. The interruption state is meant to capture events such as ill ness, injury, travel, temporary work, incarceration or academic failure. When an interruption occurs, the stock of human capital remains constant over the period. The NLSY does not contain data on parental transfers and, in particular, does not allow a distinction in income received according to the interruption status. As a consequence, we ignore the distinction between income support at school and income support when school is interrupted. ${ }^{4}$

Once the individual has entered the labor market, he receives monetary income $\omega_{t}$, which is the product of the yearly employment rate, $e_{t}$, and the wage rate, $w_{t}$. The instantaneous utility of work is

$$
U^{\text {work }}(.)=\log \left(w_{t}\right)=\log \left(e_{t} \$ w_{t}\right)
$$

and the log wage received by individual $\mathrm{i}$, at time $t$, is given by

$$
\log w_{i t}=\varphi_{1}\left(S_{i t}\right)+\varphi_{2} \cdot \text { Exper }_{i t}+\varphi_{3} \cdot \text { Exper }_{i t}^{2}+v_{i}^{w}+\varepsilon_{i t}^{w}
$$

where $\varphi_{1}\left(S_{t}\right)$ is the function representing the wage return to schooling. Both $\varphi_{2}$ and $\varphi_{3}$ are parameters to be estimated and $v_{i}^{w}$ is unobserved labor market ability a ßecting wages.

To characterize the stochastic process of the employment security variable, $e_{t}$, we assume that

$$
\log \left(e_{i t}^{\mathfrak{a}}\right)=\mu_{i t}+\varepsilon_{i t}^{e}
$$

where $e_{i t}^{\mathrm{a}}=\log \left(\frac{1}{e_{t i}}\right)$ and where $\varepsilon_{i t}^{e}$ is a random shock normally distributed with mean 0 and variance $\sigma_{e}^{2.5}$ The employment rate is also allowed to depend on accumulated human capital ( $S_{i t}$ and Exper ${ }_{i t}$ ) so that

\footnotetext{
${ }^{4} \mathrm{~W}$ hen faced with a high failure probability, some individuals may spend a portion of the year in school and a residual portion out of school. As a result, identifying a real inter ruption from a true academic failure is tenuous. In the NLSY, we ${ }^{-}$nd that more than $85 \%$ of the sample has never experienced school interruption.

${ }^{5}$ It follows that $E\left(e_{t}\right)=\mathrm{i} \exp \left(\mu_{t}+\frac{1}{2} \sigma_{e}^{2}\right)$ and that $\left.\operatorname{Var}\left(e_{t}\right)=\exp \left(2 \mu_{t}+\sigma_{e}^{2}\right) \& \exp \left(\sigma_{e}^{2}\right) \mathrm{i} 1\right)$.
} 


$$
\mu_{i t}=\kappa_{1} \phi S_{i t}+\kappa_{2} \phi \text { Exper }_{i t}+\kappa_{3} \phi \text { Exper }_{i t}^{2}+v_{i}^{e}
$$

where $v_{i}^{e}$ is an individual speci ${ }^{-} \mathrm{c}$ intercept term, $\kappa_{1}$ represents the employment security return to schooling, both $\kappa_{2}$ and $\kappa_{3}$ represent the employment security return to experience. As is usually the case in the literature, we assume that all random shocks $\left(\varepsilon_{i t}^{\xi}, \varepsilon_{i t}^{w}, \varepsilon_{i t}^{e}\right)$ are independent.

In order to express the solution to the dynamic programming problem in a compact fashion, it is convenient to summarize the state variables in a vector $\left(S_{t}, \eta_{t}\right)$ where $\eta_{t}$ is itself a vector containing the interruption status $\left(I_{t}\right)$, the utility shock $\left(\varepsilon_{t}^{\xi}\right)$, the wage shock $\left(\varepsilon_{t}^{w}\right)$, accumulated experience $\left(\right.$ Exper $\left._{t}\right)$ and a set of individual characteristics. As it is done often in dynamic optimization problems, the solution to the stochastic dynamic problem can be characterized using recursive methods (backward induction). After dropping the individual subscript for convenience, the decision to remain in school, given state variables $S_{t}$ and $\eta_{t}$, denoted $V_{t}^{s}\left(S_{t}, \eta_{t}\right)$, can be expressed as

$$
\begin{gathered}
V_{t}^{s}\left(S_{t}, \eta_{t}\right)=X^{0} \delta+\psi\left(S_{t}\right)+v^{\xi}+\varepsilon_{t}^{\xi}+\beta \mathbf{f} \zeta \pitchfork E V_{t+1}^{I}\left(S_{t+1}, \eta_{t+1}\right) \\
+(1 \mathbf{i} \zeta) \phi E M a x\left[V_{t+1}^{s}\left(S_{t+1}, \eta_{t+1}\right), V_{t+1}^{w}\left(S_{t+1}, \eta_{t+1}\right)\right] \mathbf{g}
\end{gathered}
$$

or, more compactly, as

$$
V_{t}^{s}\left(S_{t}, \eta_{t}\right)=X^{0} \delta+\psi\left(S_{t}\right)+v^{\xi}+\varepsilon_{t}^{\xi}+\beta E\left(V_{t+1} \mathbf{j} d_{t}=1\right)
$$

where $V_{t}^{I}\left(S_{t}, \eta_{t}\right)$ denotes the value of interrupting schooling acquisition and where $E\left(V_{t+1} \mathrm{j} d_{t}=1\right)$ denotes the value of following the optimal policy next period (either remain at school or start working). As we do not distinguish between income support while in school and income support during an interruption, the value of entering the interruption status, $V_{t+1}^{I}\left(S_{t}, \eta_{t}\right)$, can be expressed in a similar fashion.

The value of stopping school (that is entering the labor market) at the beginning of period $\mathrm{t}$, at wage $\mathrm{w}_{t}$ and with $S_{t}$ years of schooling, while taking into account the distribution of $e_{t}$ (because $e_{t}$ is unknown when $w_{t}$ is drawn), $V_{t}^{w}\left(S_{t}, \eta_{t}\right)$, is given by

$$
V_{t}^{w}\left(S_{t}, \eta_{t}\right)=\log \left(w_{t} \pitchfork e_{t}\right)+\beta E\left(V_{t+1} \mathbf{j} d_{t}=0\right)
$$

where $E\left(V_{t+1} \mathrm{j} d_{t}=0\right)$ is simply

$$
E\left(V_{t+1} \mathbf{j} d_{t}=0\right)={ }_{j=t+1}^{X^{T}} \beta^{j \mathrm{i}(t+1)}\left(\mathbf{i} \exp \left(\mu_{j}+\frac{1}{2} \sigma_{e}^{2}\right)+\varphi_{1}\left(S_{j}\right)+\varphi_{2} \cdot \text { Exper }_{j}+\varphi_{3} \cdot \text { Exper }_{j}^{2}\right)
$$

Using the terminal value as well as the distributional assumptions about the stochastic shocks, the probability of choosing a particular sequence of discrete choice can readily be expressed in closed-form. 


\subsection{A bilities in School and in the Labor Market}

The ${ }^{-}$rst model speci ${ }^{-}$cation (Model 1 ) is constructed so to separate and quantify the contributions of individual speci ${ }^{-} \mathrm{c}$ endowments according to 2 groups; individual speci ${ }^{-} \mathrm{c}$ attributes correlated with household background variables and purely individual speci ${ }^{-} \mathrm{c}$ abilities/ tastes (orthogonal to parents' background). By conditioning on scholastic ability, Model 2 will allow us to disentangle the eßects of family or environmental in ${ }^{\circ}$ uences from innate genetic endow ments of ability.

\subsubsection{M odel 1}

A bility heterogeneity has 3 dimensions: school ability $\left(v_{i}^{\xi}\right)$, market ability a Recting wages $\left(v_{i}^{w}\right)$ and market ability a Recting employment rates $\left(v_{i}^{e}\right)$. In the ${ }^{-}$rst model speci cation, the unobserved ability regression function is given by the following expression;

$$
v_{i}^{s}=X_{i}^{Q} \gamma^{s}+v_{i}^{s}
$$

for $s=\xi, w$ and $e$. We assume that there are $K$ types of individuals and set $K=6$. Each type is endowed with a vector $\left(\gamma_{k}^{w}, \gamma_{k}^{\kappa}, \gamma_{k}^{\circ}\right)$. The probabilities of belonging to type $k, p_{k}$, are estimated using logistic transforms

$$
p_{k}=\frac{\exp \left(q_{k}\right)}{{ }_{j=1}^{6} \exp \left(q_{j}\right)}
$$

and with the restriction normalize $q_{6}$ to 0 .

Estimation of this model will require normalization. Given the absence of data on the utility of attending school, it will be impossible to separate the direct eßects of household background variables on the utility of attending school (the $\delta Q_{s}$ ) from the e ${ }^{\text {Bect }}$ of household background variables on individual school ability. As a consequence, we set $\gamma^{\xi}=0$. In practice, this normalization implies that our estimates of the eßect of parents' background are the sum of a direct erect on the utility of attending school and an indirect eßect capturing the transmission of ability across generations. ${ }^{6}$

\subsubsection{M odel 2}

The availability of data on AFQT scores is a promising avenue for disentangling the eRects of household background variables on the utility of attending school from its erects on scholastic ability. While a simple option is to estimate the

\footnotetext{
${ }^{6} \mathrm{~T}$ he degree of under-identi ${ }^{-}$cation faced in the estimation of a dynamic programming models necessitates some parametric assumptions is discussed in details in R ust (1994) and M agnac and Thesmar (2001).
} 
model conditional on AFQT scores ${ }^{7}$, we construct our estimation strategy on the idea that AFQT scores are a noisy estimator of relevant scholastic ability $\left(v_{i}^{s}\right)$ and on the fact that the relevant measure of scholastic ability $\left(v_{i}^{s}\right)$ is given by (6). That is

$$
A F Q T_{i}=v_{i}^{\xi} \pitchfork \lambda+\eta_{i}=\left(X_{i}^{0} \gamma^{\xi}+\vartheta_{i}^{\xi}\right) \phi \lambda+\eta_{i}
$$

A consistent estimator of the eßects of household background variables on $A F Q T\left(\gamma^{\xi} \phi \lambda\right)$ is easily obtained using OLS and may used at the structural estimation stage. T he orthogonal components of school and market abilities are treated as in Model 1.

\subsection{The Likelihood Function}

In order to implement the model empirically, we must make some additional assumptions. First, we only model the decision to acquire schooling beyond 6 years (as virtually every individual has completed at least six years of schooling). Second, we set $T$ (the - nite horizon) to 65 years. F inally, we set the maximum number of years of schooling $(t)$ to 22 . Constructing the likelihood function is relatively straightforward. U sing the de nitions of $d_{t}$ and $I_{t}$, it is easy to specify all transition probabilities needed to derive the likelihood function. These transition probabilities characterize the decision to leave school permanently or to continue in school. A ltogether, they represent all possible destinations.

The transition probabilities that de ${ }^{-}$ne the choice between interrupting school permanently (start working) and obtaining an additional year of schooling, are given by

$$
\begin{gathered}
\operatorname{Pr}\left(d_{t+1}=0 \mathbf{j} d_{t}=1\right)=\left(\begin{array}{ll}
1 & \zeta
\end{array}\right) \notin \operatorname{Pr}\left(V_{t}^{w}\left(S_{t}\right), V_{t}^{s}\left(S_{t}\right)\right) \\
\operatorname{Pr}\left(d_{t+1}=1 \mathbf{j} d_{t}=1\right)=(1 ; \quad \zeta) \notin \operatorname{Pr}\left(V_{t}^{w}\left(S_{t}\right)<V_{t}^{s}\left(S_{t}\right)\right) \\
\operatorname{Pr}\left(I_{t+1}=1 \mathrm{j} d_{t}=1\right)=\zeta
\end{gathered}
$$

where $\operatorname{Pr}\left(V_{t}^{w}\left(S_{t}\right), V_{t}^{s}\left(S_{t}\right)\right)$ is easily evaluated using (4) and (5). E quation (8) represents the probability of exercising the right to leave school permanently in $t+1$ (implicitly assuming $I_{t+1}=0$ ) while equation (9) represents the probability of staying in school to acquire an additional year of human capital (also implicitly assuming $I_{t+1}=0$ ). Equation (10) represents the exogenous probability of entering the interruption state. The likelihood function is constructed from data on the allocation of time between years spent in school $\left(I_{t}=0, d_{t}=1\right)$ and years

\footnotetext{
${ }^{7} \mathrm{~T}$ his approach implies that

$$
v_{i}^{\xi}=\lambda \pitchfork A F Q T_{i}+\gamma_{i}^{\xi}
$$
}


during which school was interrupted $\left(I_{t+1}=1, d_{t}=1\right)$, and on employment histories (wage/ unemployment) observed when schooling acquisition is terminated (until 1990).

Ignoring the individual identi ${ }^{-}$cation subscript, the construction of the likelihood function requires the evaluation of the following probabilities;

2 the probability of having spent at most $\tau$ years in school (including years of interruption), which can be easily derived from (8), (9) and (10).

$$
L_{1}=\operatorname{Pr}\left[\left(d_{0}=1, I_{0}\right),\left(d_{1}=1, I_{1}\right) \ldots .\left(d_{\tau}=1, I_{\tau}\right)\right]
$$

2 the probability of entering the labor market in year $\tau+1$, at observed wage $w_{\tau+1}$, which can be factored as the product of a normal conditional probability times a marginal.

$$
L_{2}=\operatorname{Pr}\left(d_{\tau+1}=0, w_{\tau+1}\right)=\operatorname{Pr}\left(d_{\tau+1}=0 \mathbf{j} w_{\tau+1}\right) \phi \operatorname{Pr}\left(w_{\tau+1}\right)
$$

2 the density of observed wages and employment rates from $\tau+2$ until 1990. U sing the fact that the random shocks a eecting the employment process and the wage process are mutually independent and are both i.i.d., the contribution to the likelihood for labor market histories observed from $\tau+2$ until 1990 is given by

$$
L_{3}=\operatorname{Pr}\left(\mathbf{f} w_{\tau+2} \mathbf{g} . \mathbf{f} w_{1990}\right)=\operatorname{Pr}\left(\mathbf{f} w_{\tau+2} \phi e_{\tau+2} \mathbf{g} \phi \ldots . . \mathbf{P r f} w_{1990} \phi_{1990}\right)
$$

The likelihood function, for a given individual and conditional on a vector of unobserved heterogeneity components $\vartheta_{j}=v^{\xi}, v^{w}, v_{j}^{e}$, is given by $L_{i}\left(\vartheta_{j}\right)=$ $L_{1 i}\left(\vartheta_{j}\right) \Phi L_{2 i}\left(\vartheta_{j}\right) \Phi L_{3 i}\left(\vartheta_{j}\right)$. The unconditional contribution to the log likelihood, for individual $i$, is therefore given by

$$
\log L_{i}=\log { }_{j=1}^{\not X=6} p_{j} \Phi L_{i}\left(. \mathrm{j} \vartheta_{j}\right)
$$

where each $p_{j}$ represents the population proportion of type $\vartheta_{j}$.

\section{Empirical R esults}

In Section 4.1, we discuss the structural estimates of the erects of household background variables on the utility of attending school and on labor market outcomes. In Section 4.2, we perform some variance decompositions in order to investigate the relative importance of household background variables and abilities in explaining di ßerences in schooling attainments and wages. In Section 4.3, we brie $e^{\circ}$ discuss the true intergenerational education correlation implied by the model and compare it with the reduced-form correlation estimates. 


\subsection{The E Rects of Family B ackground Variables}

To facilitate presentation of the results, we split the parameter estimates in 3 tables. The erects of household background variables on the utility of attending school and labor market outcomes are in Table 2A. The remaining structural parameters of the utility of attending school and the return to schooling are in Table 2B. The estimates summarizing the distribution of unobserved heterogeneity (lab or market ability, taste for schooling) are found in Table 2C.

As the principal objective of this paper is to eval uate the relative importance of household background variables and unobserved abilities, we do not discuss all parameter estimates in details. Instead, we focus on those that will enable us to answers the basic questions raised above. An in-depth discussion of the return to schooling and the goodness of ${ }^{-} t$ for a similar model speci ${ }^{-}$cation is found in Belzil and Hansen (2002). ${ }^{8}$

\subsubsection{Parameter Estimates in M odel 1}

The parameter estimates for the e®ects of household background variables on the utility of attending school and labor market outcomes for Model 1 are found in Table 2A (column 1). As explained before, this model speci cation does not all ow for a separate identi cation of the eßects of household background variables on the utility of attending school and on scholastic ability. The normalization imposed at the estimation stage implies that all eßects of household background variables on schooling attainments are captured in the utility of attending school (the $\delta \theta_{3}$ ).

The estimates indicate clearly that, other things equal, the utility of attending school is increasing in father's education (0.0205) and household income (0.0017). Interestingly, the eßect of female education is negative $(-0.0080)$. The relatively weak eßect of female education may be explained by the fact that more educated females tend to work more in the labor market and spend less time with their children. The results for siblings $(-0.0157)$ indicate that those raised in families with smaller number of children tend to have a higher utility of attending school while those raised in a nuclear family enjoy a higher utility of attending school (0.0387). F inally, those raised in the south $(-0.0412)$ and in rural areas $(-0.0618)$ experience a lower utility of attending school. Our estimate of the yearly discount rate $\left(0.33 \%\right.$ per year) is relatively low. It may however be a re ${ }^{\circ}$ ection of the young age at which schooling decisions are made and, in particular, of the very high survival probability of young white males.

W hile the e Rects of household background variables on labor market outcomes

\footnotetext{
${ }^{8} \mathrm{As}$ documented in Belzil and Hansen (2002), the estimates of the wage equation reveal that assuming constant marginal returns to schooling is a serious mistake. The high level of signi $^{-}$cance of the parameter estimates for the spline functions ( $T$ able $2 \mathrm{~B}$ ) indicates that a model with constant marginal (local) returns would be strongly rejected.
} 
are weaker, there is supp ort for the hyp othesis that labor market ability is correlated with household background variables even after conditioning on schooling. The positive erects of father's education (around 0.0106) on log wages indicate that father's education increases wages by $1 \%$. As for the utility of attending school, the erect of female education on wages is found to be negative $(-0.0144)$. Not surprisingly, household income, which is a measure of parents' market skills, increases wages. The estimate $(0.0012)$ is highly signi ${ }^{-}$cant. The number of siblings present in the household has a signi ${ }^{-}$cant negative e eect on wage ability $(-0.0084)$. Being raised by both parents (in a nuclear family) increases wages $(0.0225)$ while being raised in the south or in rural areas reduce wages $(-0.0363$ and -0.0591 respectively). Taken as a whole, there is therefore overwhelming evidence that school and labor market abilities are strongly correlated with household background variables. Furthermore, all 7 variables are found to have a signi ${ }^{-}$cant e erect on wages as well as on the utility of attending school. ${ }^{9}$ Overall, the e Rects of parents background variables on employment rates are of the same signs as the eßects on wages but less signi ${ }^{-}$cant. For instance, female education, family income and the nuclear family indicator have an insigni ${ }^{-}$cant impact on employment rates. ${ }^{10}$

\subsubsection{Parameter Estimates in M odel 2}

In the second model speci cation, the separate erects of household background variables on the utility of attending school and on ability in school are estimated consistently. This procedure requires the correlation between AFQT scores and parents' background variables be estimated initially by OLS. Thereafter, $\lambda$ may be estimated at the same time as other parameters or be replaced by an estimat or obtained through a full maximum likelihood procedure where A FQT scores are used as a direct measure of ability. ${ }^{11}$ As a consequence, the eßects of some of the

\footnotetext{
${ }^{9} \mathrm{~F}$ or illustrative purposes, we have also estimated a restricted version of Model 1 where hou sehold human capital does not a Bect labor market outcomes aft er conditioning on schooling. The di ßerences in the parameter estimates of the househ old human capital variables between the restricted and unrest rict ed ver sions indicate that ignoring the eßects of household char acteristics on labor market outcome will lead to a serious under-estimation of the eßect of household background variables on the utility of attending school. This is particularly true for father's education, household income and siblings. This is explained by the fact that, in the most general model, household human capital raises absolute advantages in the labor market. Based on standard likelihood ratio tests, the restricted version of the model is strongly rejected.

${ }^{10} \mathrm{~T}$ he estimates reported in Table $2 \mathrm{C}$ illustrate the importance of unobserved abilities. There is a relatively important variation in the individual speci ${ }^{-} \mathrm{c}$ intercept terms of the utility of attending school as well as in the intercept terms of the wage function. Overall, those types end owed with a high school ability are also end owed with a high wage intercept. This is evidence of a positive correlation between school and market ability. For more details on the $\backslash$ A bility B ias" and the $\backslash$ Discount Rate Heterogeneity Bias", see Belzil and Hansen (2001).

${ }^{11}$ It turns out that the two procedures are practically equivalent. In what follows, we report the estimates obtained when $\hat{\lambda}$ is 0.0308 (the value obtained when the structural model was
} 
parents background variables on the utility of school should be lower than those reported in column 1 (for Model 1 ). This claim is easily veri ${ }^{-}$ed upon looking at the structural estimates reported in the second column of Table $2 \mathrm{~A}$.

Except for mother's education, the estimates of the eßects of household background variables on scholastic ability are of the same sign as the eßects on the utility of attending school. In particular, we ${ }^{-}$nd that mother's education, father's education and family income are positively corr elated with scholastic ability. A fter conditioning on scholastic ability, two of the most important household background variables, father's education and household income, are strongly reduced. Father's education is lowered from 0.0205 to 0.0154 and household income from 0.0017 to 0.0009 . The eßect of mother's education remains negative and increases in absolute value from -0.0080 to -0.0131 . T his may be explained by the fact that, given ability, mother's labor supply (highly correlated with mother's schooling) might be detrimental to child development. While this hypothesis is often advanced to explain the weak (or negative) correlation between schooling attainments and mother's schooling observed in reduced-form estimates, there exist no strong empirical evidence on the causal e ${ }^{\circledR e c t}$ of female labor supply on schooling attainments (Blau and G rossberg, 1992). A similar pattern is observed for the regional indicator and the rural/ urban indicator. The indicator for the family composition (Nuclear) is the only parameter estimate that has increased.

\subsection{The Relative Importance of household background variables and A bility in Explaining Individual School- ing Attainments and Wages}

At this stage, two questions naturally arise. What is the relative importance of household background variables and individual unobserved abilities in explaining individual schooling attainments? What is the relative importance of household background variables and individual unobserved abilities in explaining labor market wages? To investigate these issues, we simulated the model and generated 200,000 observations on schooling attainments and wages. Using standard regression techniques, we estimated the erects of individual speci ${ }^{-} \mathrm{c}$ endowments on schooling attainments. Using the simulations, it is possible to impute a fraction of schooling and wages explained by each set of determinants (parents background variables vs unobserved abilities and tastes). These variance decompositions are summarized in Table 3.

estimated with AFQT scores adjusted for age). 


\subsubsection{Schooling Attainments}

The results of the simulations obtained for both model speci ${ }^{-}$cations illustrate the complementary bene ${ }^{-}$ts of estimating these 2 models. A $n$ inspection of the variance decomposition of generated schooling attainments for Model 1 , which is found in the ${ }^{-}$rst column of Table 3 , indicates that $85 \%$ of the explained variation is imputed to observed household characteristics while only $15 \%$ is imputed to purely individual speci ${ }^{-} \mathrm{c}$ unobserved abilities. While this breakdown does not o Rer the possibility to distinguish between scholastic ability and other factors, it provides a measure of the relative importance of household background variables and pure individual speci ${ }^{-} \mathrm{c}$ unobserved components. It should be noted that this does not necessarily contradict the results recently rep orted in the literature which point out that individual schooling attainments are largely explained by di ßerences in individual taste for schooling (K eaneand Wolpin, 1997 and Eckstein and Wolpin, 1999). ${ }^{12}$

As this might have been anticipated from the structural estimates, the variance decomposition obtained for Model 2 (found in the third column of Table 3) indicates that, after taking into account that scholastic abilities are potentially explained by parents background, the fraction of schooling attainments explained by individual abilities is substantially increased. Indeed, it is practically doubled and the fraction goes from $15 \%$ to $32 \%$. A ccordingly, after conditioning on abilities, household background variables explain $68 \%$ of the explained variations in schooling attainments.

Altogether, the results provide a relatively clear picture of the importance of family background variables. Given scholastic ability, household background account for $68 \%$ of the explained cross-sectional variations in schooling attainments. Interestingly, more than one half of the parents background variable variations are explained by father's and mother's schooling alone Interestingly, around one half of the residual source of explained variations due to abilities is indeed explained by family background variables. This means that, when taken as a whole, family background variables may explain up to $85 \%$ of the cross-sectional variations in schooling attainments.

\subsubsection{Wages}

W hile household background variables account for a larger share of cross-sectional di ßerences in schooling than do individual abilities, it is far from obvious that they should have a similar explanatory power on lab or market wages. B oth school and market abilities have an eRect on wages through schooling but market ability has also a direct erect on wages through the intercept terms of the wage function. The wage variance decompositions are also in Table 3.

\footnotetext{
${ }^{12}$ In K eane and W ol pin (1997) and E ckstein and W ol pin (1999), parents backgr ound variables are not used as observable characteristics.
} 
The respective variations in explained wages due to ability heterogeneity and household background variables are quite di Rerent from those observed for predicted schooling attainments. Unlike what was observed for schooling, individual di ßerences in wages are mostly explained by ability endowments. This is true in both models. In the ${ }^{-}$rst model speci ${ }^{-}$cation, parents background variables account for $27 \%$ of the explained variation while unobserved abilities (orthogonal to family background variables) account for $73 \%$. When scholastic ability is correlated with family background variables, the role of ability is even stronger. A bility endowments explain as much as $81 \%$ of wages while only $19 \%$ is explained by family background variables.

There are two main reasons for the relatively weak e®ects of parents background variables on wages (as compared to schooling). F irst, as shown by the structural estimates in table $2 \mathrm{~A}$, household background variables have a much larger e®ect on the utility of attending school than on labor market outcomes. Second, as in Belzil and Hansen (2002), the wage return to schooling is found to be quite low so that individual di ßerences in schooling cannot explain di ßerences in wages.

\subsection{The Implied Intergenerational Education Correlation and Goodness of Fit}

The eßects of individual speci ${ }^{-} \mathrm{c}$ endowments (household background variables and abilities) on schooling attainments, which have been obtained from the simulations of both models are also useful to investigate the intergenerational correlation implied by the structural model and to assess the validity of our model. These estimates may be viewed as the net e Rects of each speci ${ }^{-} \mathrm{c}$ variable on schooling attainments and wages. While OLS estimates cannot be used to investigate the relative importance of household background variables and individual speci ${ }^{-} \mathrm{c}$ unobserved heterogeneity, they may nevertheless provide a good descriptive measure of the total (unconditional) correlation between household background variables and schooling attainments. For this reason, the correlations implied by the simulations of Model 1 may be compared to OLS estimates.

The results of these regressions are found in Table 4. As normally expected, the estimates reported indicate that individual schooling attainments increase with parents' education, income and nuclear family status but decrease with number of siblings and both the south and rural indicators. They also indicate that schooling attainments increase with scholastic ability $\left(\sigma_{i}^{\xi}\right)$ but decrease with market ability $\left(\mho_{i}^{w}\right)$.

A comparison between OLS estimates (already presented in column 4 of Table 1 ) and the implied correlations associated to Model 1 (in columns 1 and 2) indicate the validity of our approach. Virtually all the estimates are close to their OLS counterparts. This is a clear indication that our model is able to ${ }^{-} t$ the data 
well. ${ }^{13}$ On the other hand, the correlations implied by Model 2 (columns 3 and 4) measure the marginal e ${ }^{\circledR e c t s}$ of family background variables, holding scholastic ability constant. As suggested by the structural estimates, these correlations are indeed weaker and re $^{\circ}$ ect the relatively strong correlation between scholastic ability and family background variables.

Overall, both the simulations and the variance decompositions provide strong evidence that father's and mother's schooling are by the most important household background variables. For instance, an increase of 1 year in both parents' education will lead to a mean increase as large as 0.3 year of schooling. To obtain a similar increase based on family income, one would require an increase in household income superior to $\$ 30,000$. These results are consistent with those reported in reduced-form literature (Cameron and Heckman, 1998).

\section{Conclusion}

We have estimated a structural dynamic programming model of schooling decisions where individual heterogeneity (observed as well as unobserved) has several dimensions; ability in school, ability in the labor market, initial endowments in household background variables and subjective discount rates. The econometric speci cation of the model is quite general. The structure of the model has allowed us to investigate the relative importance of household background variables and individual unobserved abilities in explaining cross sectional di ßerences in schooling attainments and wages.

Overall, we ${ }^{-}$nd that parents background variables have a major impact on cross-sectional di ßerences in schooling levels. Depending on whether or not ability endowments are allowed to be correlated with family background variables, household characteristics are 2.5 to 5 times more important than purely individual speci ${ }^{-} \mathrm{c}$ ability endowments. However, the eßects of parents background variables on labor market wages are found to be very minor. Wages are mostly explained by individual speci ${ }^{-} \mathrm{c}$ factors which are orthogonal to family environment factors. Indeed purely individual speci ${ }^{-} \mathrm{c}$ factors are 3 to 4 times more important than parents background variables. ${ }^{14}$

Our results suggest interesting topics for future research. Given the negative e Rect of mother's schooling on individual schooling attainments ( after conditioning on scholastic ability), it would be interesting to evaluate how household lab or supply behavior (especially mother's labor supply) a eects schooling attainments and labor market outcomes of the children. Finally, as education " nancing requires less parental transfers in a welfare state than in a liberal economy, it would

\footnotetext{
${ }^{13} \mathrm{~A}$ mor e conventional approach to model ${ }^{-} \mathrm{t}$ is to compute predict ed frequencies to empirical frequencies. As indicated in a companion paper (B elzil and $\mathrm{H}$ ansen, 2001), our model is also able to ${ }^{-} t$ the dat a very well according to this criterion.

${ }^{14} \mathrm{~T}$ his has also been pointed out in the sociological literature (see Hauser, 1998).
} 
be interesting to compare the intergenerational educat ion correlation in countries where post-secondary schooling is heavily subsidized to the one obtained for the US economy.

\section{R eferences}

[1] Belzil, Christian and Hansen, J Ärgen (2002) \U nobserved A bility and the R eturn to Schooling" Econometrica, vol 70, No 6.

[2] Belzil, C hristian and Hansen, J ̈̈rgen (2001) \The Intergenerational education Correlation and the Rate of TimeP reference" working Paper, CIRANO, M ontreal, C anada.

[3] Blau, F.D. and Grossberg, A.J (1992) \M aternal Labor Supply and Children's Cognitive Development" Review of Economics and Statistics, 74 (3), 474-481.

[4] C ameron, Stephen and Heckman, J ames (2001) \The Dynamics of E ducational A ttainments for Black, Hispanic, and W hite Males" J ournal of Political E conomy, 109 (3) , 455-499

[5] C ameron, Stephen and Heckman, J ames (1998) \Life Cycle Schooling and Dynamic Selection Bias: Models and E vidence for $F$ ive Cohorts of A merican Males" J ournal of Political Economy, 106 (2), 262-333.

[6] Eckstein, Zvi and Kenneth Wolpin (1999) \Why youth Drop Out of High School: The Impact of preferences, Opportunities and A bilities" E conometrica, vol. 67, N o. 6 (N ovember), 1295-1339.

[7] Hauser, R obert (1998) \Intergenerational Economic M obility in the United States: Measures, Di ßerentials and Trends" Working Paper, University of Wisconsin.

[8] Kane, Thomas (1994) "College Entry by Blacks since 1970: The R ole of College Costs, Family Background, and the R eturns to Education" J ournal of Political Economy, 102, 878-911.

[9] Keane, Michael P. and Wolpin, Kenneth (1997) "The Career Decisions of Y oung Men" J ournal of P olitical Economy, 105 (3), 473-522.

[10] Lucas, Robert (1988) \On the M echanics of Economic Development" J ournal of Monetary $\mathrm{E}$ conomics 22:3-42

[11] M agnac, Thierry and David Thesmar (2001) \Identifying Dynamic Discrete Decision Processes" forthcoming in E conometrica 
[12] Rust, J ohn (1994) \Structural Estimation of Markov Decision Processes" in R. Engle and D. M cFadden, Handbook of E conometrics, North-holland: A msterdam, 3081-4143.

[13] Sauer, Robert (2001) \E ducation F inancing and Lifetime Earnings". Working Paper, Brown University

[14] Topel, Robert (1999) \Labor Markets and E conomic Growth", Working Paper, University of Chicago. 
Table 1

OLS Estimates of the E Rects of Family B ackground Variables on Schooling attainments

\begin{tabular}{|c|c|c|c|c|}
\hline & (1) & $(2)$ & (3) & (4) \\
\hline Intercept & $\begin{array}{l}1.1500 \\
(0.0834)\end{array}$ & $\begin{array}{l}1.3070 \\
(0.0818)\end{array}$ & $\begin{array}{l}2.1159 \\
(0.09380\end{array}$ & $\begin{array}{l}2.1043 \\
(0.1031)\end{array}$ \\
\hline Father's educ & $\begin{array}{l}0.2565 \\
(0.0061)\end{array}$ & $\begin{array}{l}0.2199 \\
(0.0061)\end{array}$ & $\begin{array}{l}0.2073 \\
(0.0061)\end{array}$ & $\begin{array}{l}0.2073 \\
(0.00610\end{array}$ \\
\hline M other's educ & $\begin{array}{l}0.2279 \\
(0.0086)\end{array}$ & $\begin{array}{l}0.1948 \\
(0.0085)\end{array}$ & $\begin{array}{l}0.1776 \\
(0.0085)\end{array}$ & $\begin{array}{l}0.1683 \\
(0.0085)\end{array}$ \\
\hline Household I ncome & & $\begin{array}{l}0.0178 \\
(0.0006)\end{array}$ & $\begin{array}{l}0.0173 \\
(0.0006)\end{array}$ & $\begin{array}{l}0.0155 \\
(0.0007)\end{array}$ \\
\hline Siblings & & & $\begin{array}{l}-0.1391 \\
(0.0081)\end{array}$ & $\begin{array}{l}-0.1454 \\
(0.0081)\end{array}$ \\
\hline Nuclear family & & & & $\begin{array}{l}0.4312 \\
(0.0420)\end{array}$ \\
\hline Rural & & & & $\begin{array}{l}-0.0496 \\
(0.0378)\end{array}$ \\
\hline South & & & & $\begin{array}{l}-0.3478 \\
(0.0379)\end{array}$ \\
\hline $\mathrm{R}^{2}$ & 0.2553 & 0.2864 & 0.2985 & 0.3060 \\
\hline Sample size & 1708 & 1708 & 1708 & 1708 \\
\hline
\end{tabular}


Table 2A

The $E$ Rects of household background variables on the U tility of Attending School and labor M arket outcomes

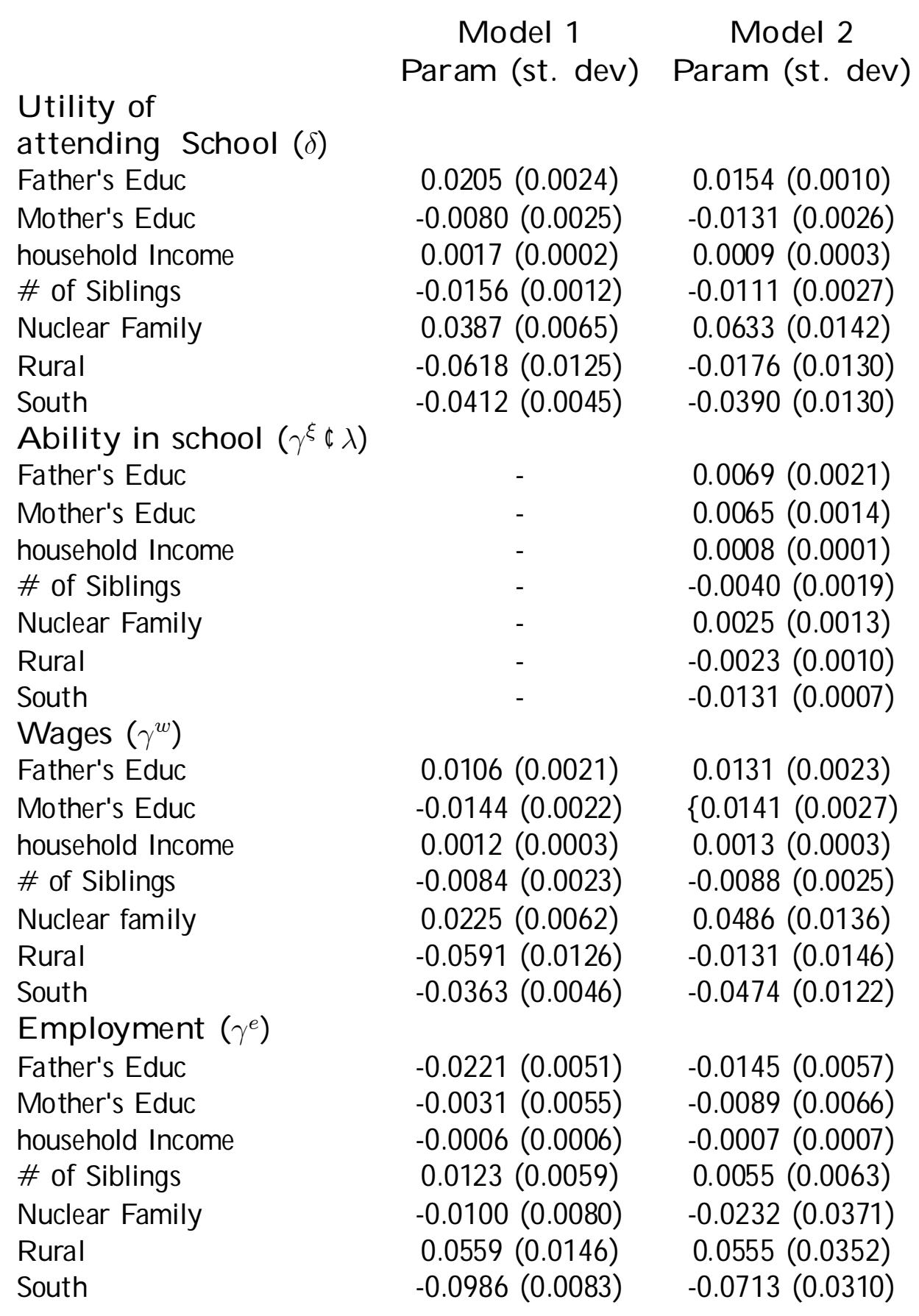

Note: Household income is divided by 1000. 
Table 2B

Other Structural Parameters

\author{
Utility in School \\ Stand.Dev. $\left(\sigma_{\xi}\right)$ \\ Splines $\delta_{7_{i} 10}$ \\ Splines $\delta_{11}$ \\ Splines $\delta_{12}$ \\ Splines $\delta_{13}$ \\ Splines $\delta_{14}$ \\ Splines $\delta_{15}$ \\ Splines $\delta_{16}$ \\ Splines $\delta_{17}$ more \\ Interruption Prob. \\ Discount Rate \\ Emp. R eturn to Schooling \\ schooling \\ experience \\ experience ${ }^{2}$ \\ std. dev $\left(\sigma_{e}\right)$ \\ Wage return to schooling \\ Spline grade 7-10 \\ Spline grade 11 \\ Spline grade 12 \\ Spline grade 13 \\ Spline grade 14 \\ Spline grade 15 \\ Spline grade 16 \\ Spline grade 17-more \\ experience \\ experience ${ }^{2}$ \\ std. dev $\left(\sigma_{w}\right)$ \\ mean log Likelihood
}

$\begin{array}{cc}\text { M odel 1 } & \text { M odel 2 } \\ \text { Param.(Std error) } & \text { Param.(Std error) } \\ 0.3793(0.0105) & 0.2175(0.0116) \\ -0.0418(0.0105) & 0.0181(0.0078) \\ 0.3793(0.0218) & -0.1250(0.0214) \\ -1.6601(0.0258) & -1.4689(0.0230) \\ -1.2814(0.0547) & -0.9828(0.0230) \\ 3.2614(0.0118) & 3.5721(0.0132) \\ -0.6729(0.0234) & -0.8231(0.0141) \\ 0.8004(0.0244) & 0.5456(0.0087) \\ -0.6330(0.0084) & -0.6190(0.0235) \\ 0.0749(0.0036) & 0.0749(0.0036) \\ 0.0033(0.0001) & 0.0045(0.0001) \\ & \\ -0.0258(0.0041) & -0.0361(0.0026) \\ -0.0146(0.0026) & -0.0148(0.0026) \\ 0.0001(0.0001) & 0.0001(0.0001) \\ 1.3160(0.0096) & 1.3250(0.0020) \\ & \\ 0.0042(0.0002) & 0.0053(0.0003) \\ 0.0079(0.0010) & 0.0051(0.0013) \\ 0.0046(0.0011) & 0.0156(0.0012) \\ 0.0171(0.0016) & 0.0236(0.0013) \\ 0.0787(0.0018) & 0.0803(0.0017) \\ -0.0154(0.0020) & -0.0246(0.0016) \\ 0.0092(0.0022) & -0.0002(0.0019) \\ -0.0124(0.0013) & -0.0183(0.0012) \\ 0.0877(0.0016) & 0.0876(0.0016) \\ -0.0030(0.0001) & -0.0029(0.0002) \\ 0.2966(0.0024) & 0.2920(0.0024) \\ -13.6638 & -13.6362 \\ & \end{array}$


Table 2C

Unobserved Heterogeneity and Type Probabilities

\begin{tabular}{|c|c|c|c|c|}
\hline \multirow{5}{*}{ Type 1} & & & $\begin{array}{l}\text { M odel } 1 \\
\text { Param (St Frror) }\end{array}$ & $\begin{array}{c}\text { Model } 2 \\
\text { Param. (St Error }\end{array}$ \\
\hline & $v_{1}^{\xi}$ & School ab. & $-2.9693(0.0108)$ & $-3.0184(0.0169)$ \\
\hline & $v_{1}^{w}$ & Wage & $1.5374(0.0105)$ & $1.3643(0.0098)$ \\
\hline & $\kappa_{01}$ & Employment & $-3.4537(0.0312)$ & $-3.4077(0.0221)$ \\
\hline & $q_{1}$ & Type $\mathrm{P}$ rob. & $0.6286(0.0560)$ & $-0.2707(0.0226)$ \\
\hline \multirow[t]{4}{*}{ Type 2} & $v_{2}^{\xi}$ & School ab. & $-2.7838(0.0125)$ & $-2.9329(0.0528)$ \\
\hline & $v_{2}^{w}$ & Wage ab. & $1.8672(0.0107)$ & $1.9673(0.0094)$ \\
\hline & $\kappa_{02}$ & Employment & $-2.4784(0.0384)$ & $-1.4417(0.0077)$ \\
\hline & $q_{2}$ & Type P rob & $-0.3823(0.0518)$ & $-2.6253(0.0075)$ \\
\hline \multirow[t]{4}{*}{ Type 3} & $v_{3}^{\xi}$ & School ab. & $-3.2766(0.0131)$ & $-3.3411(0.0217)$ \\
\hline & $v_{3}^{w}$ & Wage & $1.1951(0.0156)$ & $1.0062(0.0136)$ \\
\hline & $\kappa_{03}$ & Employment & $-3.3351(0.0381)$ & $-3.1869(0.0060)$ \\
\hline & $q_{3}$ & Type P rob & $-0.4227(0.0185)$ & $-1.7000(0.0076)$ \\
\hline \multirow[t]{4}{*}{ Type 4} & $v_{4}^{\xi}$ & School ab. & $-3.3891(0.0243)$ & $-3.3538(0.0445)$ \\
\hline & $v_{4}^{w}$ & Wage & $1.5055(0.0162)$ & $1.4291(0.0070)$ \\
\hline & $\kappa_{04}$ & Employment & $-1.5840(0.0362)$ & $-1.7157(0.0268)$ \\
\hline & $q_{4}$ & Type P rob & $-0.4513(0.0415)$ & $-0.9400(0.0067)$ \\
\hline \multirow[t]{4}{*}{ Type 5} & $v_{5}^{\xi}$ & School ab. & $-2.3878(0.0289)$ & $-2.3975(0.0182)$ \\
\hline & $v_{5}^{w}$ & Wage & $2.1162(0.0221)$ & $2.0000(0.0101)$ \\
\hline & $\kappa_{05}$ & Employment & $-3.6242(0.0224)$ & $-3.5838(0.0105)$ \\
\hline & $q_{5}$ & Type P rob & $-0.0776(0.0817)$ & $-0.9443(0.0008)$ \\
\hline \multirow[t]{4}{*}{ Type 6} & $v_{6}^{\xi}$ & School ab. & $-2.7010(0.0184)$ & $-2.7358(0.0166)$ \\
\hline & $v_{6}^{w}$ & Wage & $1.8016(0.0120)$ & $1.6707(0.0130)$ \\
\hline & $\kappa_{06}$ & Employment & $-3.7365(0.0173)$ & $-3.4238(0.0157)$ \\
\hline & $q_{6}$ & Type P rob & 0.0 (normalized) & 0.0 (normalized) \\
\hline
\end{tabular}

N ote: The respective type probabilities are $0.32,0.12,0.11,0.11,0.16$ and 0.17 in M odel 1, and 0.27, 0.03,0.06,0.14, 0.14 and 0.36 in M odel 2. 
Table 3

Sources of Variations in Schooling A ttainments and Wages

Household

M odel 1

(1)

(2)

M odel 2

(3) (4)

$\%$ Schooling \% wages \% Schooling \% wages

explained by explained by explained by explained by

background

$\begin{array}{lllll}\begin{array}{l}\text { Parents' } \\ \text { education }\end{array} & 71.3 \% & 18.7 \% & 54.8 \% & 12.5 \%\end{array}$

Parents' educ

$77.4 \%$

$23.3 \%$

$62.2 \%$

$16.9 \%$

and income

All household

$84.8 \%$

$27.4 \%$

$67.6 \%$

$19.3 \%$

variables

Abilities
A bilities (unobs)
$15.2 \%$
$72.6 \%$

A bilities (obs\&unobs)

$32.4 \%$

$80.7 \%$

N ote: The percentages are expressed as a fraction of the total variations imputed to parents' background variables and unobserved heterogeneities. 
Table 4

Correlations between Schooling Attainments and

Parents' background variables implied by the Structural Estimates
(1)
(2)
(3)
(4)

\begin{tabular}{|c|c|c|c|c|}
\hline M odel & Model 1 & Model 1 & Model 2 & M odel \\
\hline Father's educ & $\begin{array}{l}0.1934 \\
(0.0019)\end{array}$ & $\begin{array}{l}0.1932 \\
(0.0018)\end{array}$ & $\begin{array}{l}0.1539 \\
(0.0057)\end{array}$ & $\begin{array}{l}0.1707 \\
(0.0057)\end{array}$ \\
\hline M other's educ & $\begin{array}{l}0.1444 \\
(0.0227)\end{array}$ & $\begin{array}{l}0.1439 \\
(0.0026)\end{array}$ & $\begin{array}{l}0.0935 \\
(0.0076)\end{array}$ & $\begin{array}{l}0.0526 \\
(0.0079)\end{array}$ \\
\hline H ousehold Income & $\begin{array}{l}0.0106 \\
(0.0002)\end{array}$ & $\begin{array}{l}0.0106 \\
(0.0002)\end{array}$ & $\begin{array}{l}0.0122 \\
(0.0006)\end{array}$ & $\begin{array}{l}0.0106 \\
(0.0006)\end{array}$ \\
\hline Siblings & $\begin{array}{l}-0.1531 \\
(0.0025)\end{array}$ & $\begin{array}{l}-0.1527 \\
(0.0024)\end{array}$ & $\begin{array}{l}-0.0967 \\
(0.0075)\end{array}$ & $\begin{array}{l}-0.1308 \\
(0.0075)\end{array}$ \\
\hline $\mathrm{N}$ uclear family & $\begin{array}{l}0.4136 \\
(0.0132)\end{array}$ & $\begin{array}{l}0.4163 \\
(0.0127)\end{array}$ & $\begin{array}{l}0.3242 \\
(0.0389)\end{array}$ & $\begin{array}{l}0.4104 \\
(0.0389)\end{array}$ \\
\hline R ural & $\begin{array}{l}0.0943 \\
(0.0118)\end{array}$ & $\begin{array}{l}0.0894 \\
(0.0114)\end{array}$ & $\begin{array}{l}-0.0353 \\
(0.0337)\end{array}$ & $\begin{array}{l}-0.0551 \\
(0.0349)\end{array}$ \\
\hline South & $\begin{array}{l}-0.3981 \\
(0.0119)\end{array}$ & $\begin{array}{l}-0.3976 \\
(0.0115)\end{array}$ & $\begin{array}{l}-0.2507 \\
(0.0351)\end{array}$ & $\begin{array}{l}-0.3324 \\
(0.0351)\end{array}$ \\
\hline$\gamma_{\imath}^{\xi} \propto 10$ & $\begin{array}{l}0.4533 \\
(0.0164)\end{array}$ & & $\begin{array}{l}0.2401 \\
(0.0544)\end{array}$ & \\
\hline$\gamma_{i}^{w} \propto 10$ & $\begin{array}{l}-0.5495 \\
(0.1550)\end{array}$ & & $\begin{array}{l}-0.2222 \\
(0.0487)\end{array}$ & \\
\hline$\sigma_{i}^{e} \propto 10$ & $\begin{array}{l}0.2991 \\
(0.0906)\end{array}$ & & $\begin{array}{l}0.0547 \\
(0.01320\end{array}$ & \\
\hline $\mathrm{R}^{2}$ & 0.3143 & 0.2667 & 0.2975 & 0.2373 \\
\hline
\end{tabular}




\section{Appendix \\ The Data}

The sample used in the analysis is extracted from 1979 youth cohort of the The National Longitudinal Survey of Youth (NLSY). The NLSY is a nationally representative sample of 12,686 A mericans who were 14-21 years old as of J anuary 1, 1979. After the initial survey, re-interviews have been conducted in each subsequent year until 1996. In this paper, we restrict our sample to white males who were age 20 or less as of J anuary 1, 1979. We record information on education, wages and on employment rates for each individual from the time the individual is age 16 up to December $31,1990 .{ }^{15}$

The original sample contained 3,790 white males. However, we lacked information on household background variables (such as household income as of 1978 and parents' education). ${ }^{16}$ The age limit and missing information regarding actual work experience further reduced the sample to 1,710. Descriptive statistics are found in Table 1.

B efore discussing descriptive statistics, it is important to describe the construction of some important variables. In particular, both the schooling attainment variable and the experience variable deserve some discussions. First, the education length variable is the reported highest grade completed as of $M$ ay 1 of the survey year. Individuals are also asked if they are currently enrolled in school or not. This question allows us to identify those individuals who are still acquiring schooling and therefore to take into account that education length is right-censored for some individuals. It also helps us to identify those individuals who have interrupted schooling. Overall, young individuals tend to acquire education without interruption. In our sample, only 306 individuals have experienced at least one interruption (Table 1). This represents only $18 \%$ of our sample and it is along the lines of results reported in Keane and Wolpin (1997). As well, we note that interruptions tend to be short. A Imost half of the individuals (45\%) who experienced an interruption, returned to school within one year while $73 \%$ returned within 3 years.

Second, unlike many studies set in a reduced-form which use potential experience (age -education- 6), we use data on actual experience. The availability of data on actual employment rates allows use to estimate the employment security return to schooling. More details can be found in Belzil and Hansen (2001).

\footnotetext{
${ }^{15} \mathrm{~T}$ he reason for not including information beyond 1990 is that the wage data do not appear reliable for these more recent waves.

${ }^{16}$ W e lost about $17 \%$ of the sample due to missing information regarding family income and about about $6 \%$ due to missing information regarding parents' education.
} 
Table A 1 -

Descriptive Statistics

$\begin{array}{llll}\text { Household Income/ } 1000 & 36,904 & 27.61 & 1710 \\ \text { father's educ } & 11.69 & 3.47 & 1710 \\ \text { mother's educ } & 11.67 & 2.46 & 1710 \\ \text { \# of siblings } & 3.18 & 2.13 & 1710 \\ \text { prop. raised in urban areas } & 0.73 & - & 1710 \\ \text { prop. raised in south } & 0.27 & - & 1710 \\ \text { prop in nuclear family } & 0.79 & - & 1710 \\ \text { Schooling completed (1990) } & 12.81 & 2.58 & 1710 \\ \text { \# of interruptions } & 0.06 & 0.51 & 1710 \\ \text { duration of interruptions (year) } & 0.43 & 1.39 & 1710 \\ \text { wage 1979 (hour) } & 7.36 & 2.43 & 217 \\ \text { wage } 1980 \text { (hour) } & 7.17 & 2.74 & 422 \\ \text { wage } 1981 \text { (hour) } & 7.18 & 2.75 & 598 \\ \text { wage } 1982 \text { (hour) } & 7.43 & 3.17 & 819 \\ \text { wage } 1983 \text { (hour) } & 7.35 & 3.21 & 947 \\ \text { wage } 1984 \text { (hour) } & 7.66 & 3.60 & 1071 \\ \text { wage } 1985 \text { (hour) } & 8.08 & 3.54 & 1060 \\ \text { wage } 1986 \text { (hour) } & 8.75 & 3.87 & 1097 \\ \text { wage } 1987 \text { (hour) } & 9.64 & 4.44 & 1147 \\ \text { wage } 1988 \text { (hour) } & 10.32 & 4.89 & 1215 \\ \text { wage } 1989 \text { (hour) } & 10.47 & 4.97 & 1232 \\ \text { wage } 1990 \text { (hour) } & 10.99 & 5.23 & 1230 \\ \text { Experience 1990 (years) } & 8.05 & 11.55 & 1230\end{array}$

Note: Household income and hourly wages are reported in 1990 dollars. Household income is measured as of $M$ ay 1978. The increasing number of wage observations is explained by the increase in participation rates. 


\section{IZA Discussion Papers}

\begin{tabular}{|c|c|c|c|c|}
\hline No. & Author(s) & Title & Area & Date \\
\hline 958 & $\begin{array}{l}\text { T. Brück } \\
\text { J. P. Haisken-DeNew } \\
\text { K. F. Zimmermann }\end{array}$ & $\begin{array}{l}\text { Creating Low Skilled Jobs by Subsidizing } \\
\text { Market-Contracted Household Work }\end{array}$ & 5 & $12 / 03$ \\
\hline 959 & $\begin{array}{l}\text { T. Bauer } \\
\text { H. Bonin } \\
\text { U. Sunde }\end{array}$ & $\begin{array}{l}\text { Real and Nominal Wage Rigidities and the Rate } \\
\text { of Inflation: Evidence from West German Micro } \\
\text { Data }\end{array}$ & 1 & $12 / 03$ \\
\hline 960 & $\begin{array}{l}\text { A. Constant } \\
\text { K. F. Zimmermann }\end{array}$ & $\begin{array}{l}\text { Circular Movements and Time Away from the } \\
\text { Host Country }\end{array}$ & 1 & $12 / 03$ \\
\hline 961 & $\begin{array}{l}\text { C. N. Teulings } \\
\text { C. G. de Vries }\end{array}$ & $\begin{array}{l}\text { Generational Accounting, Solidarity and Pension } \\
\text { Losses }\end{array}$ & 3 & $12 / 03$ \\
\hline 962 & $\begin{array}{l}\text { L. Goerke } \\
\text { M. Pannenberg }\end{array}$ & $\begin{array}{l}\text { Norm-Based Trade Union Membership: } \\
\text { Evidence for Germany }\end{array}$ & 3 & $12 / 03$ \\
\hline 963 & $\begin{array}{l}\text { L. Diaz-Serrano } \\
\text { J. Hartog } \\
\text { H. S. Nielsen }\end{array}$ & $\begin{array}{l}\text { Compensating Wage Differentials for } \\
\text { Schooling Risk in Denmark }\end{array}$ & 5 & $12 / 03$ \\
\hline 964 & $\begin{array}{l}\text { R. Schettkat } \\
\text { L. Yocarini }\end{array}$ & $\begin{array}{l}\text { The Shift to Services: } \\
\text { A Review of the Literature }\end{array}$ & 5 & $12 / 03$ \\
\hline 965 & $\begin{array}{l}\text { M. Merz } \\
\text { E. Yashiv }\end{array}$ & Labor and the Market Value of the Firm & 1 & $12 / 03$ \\
\hline 966 & T. Palokangas & $\begin{array}{l}\text { Optimal Taxation with Capital Accumulation } \\
\text { and Wage Bargaining }\end{array}$ & 3 & $12 / 03$ \\
\hline 967 & $\begin{array}{l}\text { M. Lechner } \\
\text { R. Vazquez-Alvarez }\end{array}$ & $\begin{array}{l}\text { The Effect of Disability on Labour Market } \\
\text { Outcomes in Germany: Evidence from Matching }\end{array}$ & 6 & $12 / 03$ \\
\hline 968 & $\begin{array}{l}\text { M. Blázquez } \\
\text { M. Jansen }\end{array}$ & $\begin{array}{l}\text { Efficiency in a Matching Model with } \\
\text { Heterogeneous Agents: Too Many } \\
\text { Good or Bad Jobs? }\end{array}$ & 1 & $12 / 03$ \\
\hline 969 & $\begin{array}{l}\text { J.-P. Schraepler } \\
\text { G. G. Wagner }\end{array}$ & $\begin{array}{l}\text { Identification, Characteristics and Impact of } \\
\text { Faked Interviews in Surveys }\end{array}$ & 7 & $12 / 03$ \\
\hline 970 & $\begin{array}{l}\text { G. Kertesi } \\
\text { J. Köllõ }\end{array}$ & $\begin{array}{l}\text { Fighting "Low Equilibria" by Doubling the } \\
\text { Minimum Wage? Hungary's Experiment }\end{array}$ & 4 & $12 / 03$ \\
\hline 971 & $\begin{array}{l}\text { J. De Loecker } \\
\text { J. Konings }\end{array}$ & $\begin{array}{l}\text { Creative Destruction and Productivity Growth in } \\
\text { an Emerging Economy: Evidence from } \\
\text { Slovenian Manufacturing }\end{array}$ & 4 & $12 / 03$ \\
\hline 972 & J. Köllõ & $\begin{array}{l}\text { Transition on the Shop Floor - The Restructuring } \\
\text { of a Weaving Mill, Hungary 1988-97 }\end{array}$ & 4 & $12 / 03$ \\
\hline 973 & $\begin{array}{l}\text { C. Belzil } \\
\text { J. Hansen }\end{array}$ & $\begin{array}{l}\text { Structural Estimates of the Intergenerational } \\
\text { Education Correlation }\end{array}$ & 1 & $12 / 03$ \\
\hline
\end{tabular}

An updated list of IZA Discussion Papers is available on the center's homepage www.iza.org. 